Article

\title{
Is Transportation Infrastructure Important to the One Belt One Road (OBOR) Initiative? Empirical Evidence from the Selected Asian Countries
}

\author{
Kwang-Jing Yii *, Kai-Ying Bee, Wei-Yong Cheam, Yee-Lee Chong and Ching-Mei Lee \\ Faculty of Business and Finance, Universiti Tunku Abdul Rahman, Jalan Universiti Bandar Barat, \\ 31900 Kampar, Perak, Malaysia; bbeekaiying@yahoo.com (K.-Y.B.); kencheam34@live.com.my (W.-Y.C.); \\ yeeleec0205@gmail.com (Y.-L.C.); jessielee95@1utar.my (C.-M.L.) \\ * Correspondence: yiikj@utar.edu.my; Tel.: +60-16-8302623
}

Received: 14 October 2018; Accepted: 8 November 2018; Published: 10 November 2018

check for updates

\begin{abstract}
The One Belt One Road (OBOR) initiative is implemented to improve the linkage between China and its neighboring countries in terms of economic ties, connectivity, partnership, and security cooperation. The crucial challenge encountered in OBOR initiative is the different gauge standards from different countries in the development of railway along the Silk Road. Another issue arose from the regulation of education sector in the aspect of quality, cost, and efficiency. To the best of our knowledge, there is still lack of study on the transportation infrastructure and education towards the GDP in the selected Asian countries, especially for Central Asia. Therefore, this study aims to examine the impact of OBOR initiative and its importance towards economic growth by further investigating the determinants such as transportation infrastructure, education, labor, trade, and inflation rate. This study employs panel data analysis using the annual data from the period of 2000-2015. The selected Asian countries are divided into three regions, namely Central Asia (Kazakhstan, Kyrgyz Republic, Tajikistan, Turkmenistan, Uzbekistan), ASEAN (Thailand, Indonesia, Vietnam, Malaysia), and East Asia (China, Mongolia). Besides, we use fixed effect model (FEM) to obtain the results based on the support of Hausman test and Poolability F-test. The findings reveal that transportation infrastructure possess a positive effect on GDP. Surprisingly, education is negatively related to GDP. With this, policy makers are suggested to encourage OBOR countries to expand and upgrade their system in terms of transportation infrastructure, human capital, culture, and education. In future studies, the advanced model is recommended to investigate the pre- and post-efficiency of OBOR initiative.
\end{abstract}

Keywords: One Belt One Road (OBOR); economic growth; transportation infrastructure; education; Asian countries

\section{Introduction}

The One Belt One Road (OBOR) initiative is the combination of the Silk Road Economic Belt and the 21st century Maritime Silk Road, and is also known as the Belt and Road (B\&R) and the Belt and Road Initiative (BRI). This initiative aims to improve the linkage between China and its neighboring countries in order to promote economic ties, connectivity, partnership, and security cooperation. OBOR is covered by regions, which are Central Asia, Eastern Europe, the Middle East, Russia, South Asia, and Southeast Asia, with the involvement of 65 countries [1]. OBOR mainly focuses on infrastructure investment, construction materials, railway, iron and steel, and information communication [2]. With its participation in OBOR, Asia is promoted as a world industrial chain among the regions [3]. Ultimately, OBOR emphasizes China's major role as a central trading network in global affairs [4]. For instance, China successfully organizes several financial authorities, such as the 
Asian Infrastructure Development Bank (AIIB) and Silk Road Fund in order to support the projects along the OBOR.

There are five key cooperations for OBOR to enhance connectivity in promoting the development of policy coordination, expanding infrastructure connectivity, improving financial support and unimpeded trade, and deepening interpersonal bonds. Policy coordination refers to the countries along the belt and road jointly figuring out an effective cooperation in various fields to build up the initiative. This helps to resolve the problem of differences in political system and culture among the BRI countries when dealing with this large-scale project. On the other hand, Huang [5] asserts that financial cooperation is the key determinant to promote equality in monetary policy, investment between countries within the route, foreign exchange in trade, the monitoring of financial risk, and the enhancement of the capability of managing the risk through regional planning. The initiative also emphasizes the elimination of the barriers of investment and trade, reducing investment and trade costs, as well as promoting economic integration in order to create a free-trade zone among countries. Additionally, one of the priorities of OBOR is to augment investment in infrastructure such as telecommunications, airports, roads, railways, ports, energy pipelines, and fiber-optic lines [6]. Furthermore, the mechanisms for culture, talent, academic exchange, and training are important in developing interpersonal bonds as a part of the OBOR initiative.

OBOR includes 65 countries, each of which has different races, cultures, religions, languages, and economic and political systems. This causes the OBOR initiative to encounter several internal and external challenges, especially in the selected Asian countries. According to Yunling [7], one of the internal problems is the expectation of immediate and visible return. The OBOR initiative project refers to a larger-scale infrastructure investment in the long term. The instant decision without further consideration in the investment of the OBOR initiative leads to duplication and wastage and, in turn, to the reduction of the economic growth of the country. Most of the local regions concentrate on their own interest rather than on achieving the national strategy when developing a plan for the collaboration with other countries. As a result, the development of China's provinces in the OBOR initiative has been halted. Furthermore, the reckless growth of the OBOR initiative also leads to missing segments among the participating countries. Consequently, inadequate benefit is obtained from the driving effect of the railway and the competitive transportation market [8].

One of the OBOR external challenges is "open but blocked" in Central Asia. Although the development of railway along the Silk Road is stimulated in many countries, the different gauge standards renders China's railway unable to connect seamlessly to those of Central Asian and other countries [8]. Therefore, the existing transport capacity and service quality are not easily able to meet the requirements of modern freight and passenger transport. Meanwhile, the Asian Development Bank [9] indicates that the enormous cost of private education is the main problem related to privatization in the Association of Southeast Asian Nations (ASEAN). Private institutions are seen as a crucial complement to public institutions. It is crucial to enhance the demand for higher education. However, there is concern about how to regulate in the aspect of quality, cost, and efficiency, especially for Myanmar, Laos, Cambodia, Thailand, and Vietnam. Moreover, Laos and Cambodia struggle to provide basic infrastructure for higher education. This will also limit the available skilled labor and decrease the national economic growth.

China's firms are able to export their goods globally with their competitive pricing. However, people are still concerned about the shoddy products and services produced by China [10]. This reduces the demand for goods and services; subsequently, the labor force is decreased, which raises the unemployment rate and, in turn, deteriorates national economic growth. To ensure the success of this competitive pricing strategy, strong regulation, effective project management, sensitive construction measures, and careful consideration of environmental and social impacts should be taken seriously. The implementation of OBOR allows China's business practice to overflow around the world with its product. This eventually negatively impacts the labor force and industrial sector in the participating countries. Garcia [11] stated that there were large waves of migration in the past 10 to 15 years as 
investors realized that the low cost of goods would severely affect production at the domestic level. For instance, Chinese companies tend to invest abroad, especially in construction companies, as these bring in their own labor to a particular country. However, this does not provide job opportunities in the host countries, and also brings up racial issues among the local citizens due to competition in the labor force. Based on Okun's law, a reduction in labor force will decrease economic growth. Unfortunately, there is always an issue of international trade between China and other countries. The problem in the choice of trading arises as OBOR connects China to most Asian and European countries. For instance, the trading policy in Kyrgyzstan is established with the cheapest and most effective trading between China and Central Asia. However, there is no further planning in the trade liberalization, which leads to disagreement between the two countries.

Various factors indicate that the OBOR initiative gives priority to the development of transportation services. For instance, the Pan-Asia railway network is planned to connect China with countries in Southeast Asia such as Thailand, Malaysia, and Singapore, while the Baku-Tbilisi-Kars (BTK) railway links Central Asia and China to Europe, from Azerbaijan to Turkey. However, there is still a lack of research in the transportation infrastructure, especially in Southeast Asia and Central Asia. This research gap shows that the role of transportation infrastructure should be elucidated. Education plays an important role in human capital development, which drives the economic growth of a country. The World Bank [12] indicates that an upward trend in education is associated with the growth of GDP. It is important to address the issues of education which occur in OBOR participant countries. However, the majority of past studies have merely focused on the importance of the OBOR initiative in China, not other participant countries. Therefore, this study aims to examine the relationship between transportation infrastructure, education, trade, labor force, and inflation, on the economic growth of three regions-East Asia, Central Asia, and Southeast Asia. The findings of this study will provide further insight to the relevant authorities in order to ensure the effective and successful implementation of the OBOR initiative. Furthermore, this work is also relevant to other researchers as a benchmark for the investigation of the efficiency of the OBOR initiative.

The remainder of this study is organized as follows: Section 2 presents a literature review including the relevant theoretical models and past studies on the determinants of economic growth; Section 3 shows the methodology to be employed; Section 4 presents the empirical results and discussions; and Section 5 concludes the study with the policy implications.

\section{Literature Review}

\subsection{Transportation Infrastructure}

Under the development of the empirical model, salient paradox theory supports the idea that transportation infrastructure has a significant impact on a country's economic expansion. Salient paradox theory involves contradictory interrelated elements which appear simultaneously over time [13]. These contradictory elements include tensions between maximizing profits and improving social welfare [14]. Transportation infrastructure is the incentive to drive economic development and social welfare which enhance production and investment performance in the private sector [15]. The macroand micro-paradox seem to be in opposition regarding the impact of infrastructure investment on economic prosperity. The macro-level paradox argues that increased public sector investment in transportation infrastructure will increase the efficiency and profitability of the business sector and thus stimulate an increase in business investment in private capital [16]. In contrast, the micro-level paradox shows that the financial, social, and environmental performance of infrastructure investment is poor [17]. For instance, in the mid-1980s, the scale and speed of China's delivery of a large stock of infrastructure evoked awe, while in contrast democratic countries live in the "slow lane" [18].

Zou et al. [19] employed the Granger causality test to analyze the relationship between transport construction and economic growth across provinces in the Chinese economy. Their findings show that the construction of railway has a significant effect on regional growth. This implies that more 
investment in roads and railways is urgently needed to explore more economy of scale, because the railway density is much lower than the satiation point in the provinces. This finding is supported by Yang and Ma [20] who studied the relationship between traffic infrastructure investment and economic growth in China's western provinces (Shanxi, Gansu, Ningxia, Qinghai, and Xinjiang). Pradhan et al. [21] used a data set including 34 member countries of the Organization for Economic Co-operation and Development (OECD). The finding also supports the existence of co-integration between transportation and communication infrastructure investment and economic growth in the long run, and bidirectional Granger causality effect. This is because better economic development usually provides necessary financial and technical support for transport and communication infrastructure investment, as it is a productive stimulus in contributing to the economic growth of country.

According to Ylander [22], ordinary least squares (OLS) analysis showed that railways have a positive effect on GDP growth. If railways connect to OBOR infrastructure projects, this will positively contribute to GDP growth in the selected provinces in China. Shi et al. [23] employed a vector error correction model and found that railway infrastructure contributes significantly to the GDP of central and western regions. This reflects the important role of railways in connecting inland provinces to the coast.

Additionally, Shabani and Safaie [24] performed maximum likelihood analysis to study the spatial spillover effect of road and railway transport infrastructure on economic growth in the provinces of Iran. Their findings show that railway transport has a positive spatial spillover effect in terms of direct effect and an indirect effect on regional economic growth. The positive spatial spillover effect indicates that the development of rail transportation infrastructure in a province leads to an increase in the economic growth of neighboring provinces. Li et al. [25] utilized a spatial panel model to investigate the spatial spillover effect of transport infrastructure on the New Silk Road Economic Belt and its regional economic growth. It was found that a strong spatial spillover effect is exerted on regional economic growth by transport infrastructure. This is supported by the studies of Liu and Wang [26] and Wang et al. [27] who also found that transport infrastructure imposes a spatial spillover effect on economic growth.

Furthermore, Yoshino and Abidhadjaev [28] employed difference-in-difference estimation to examine the impact of railway construction connection on economic growth in Uzbekistan. Their findings show that a railway connection generates positive impact for the region as well as the distant parts of country. Meanwhile, Villafuerte et al. [29] applied a global trade analysis project (GTAP) model to assess the impact of OBOR on Asia's international transport services. The GDP growth in Central, West, and South Asia is increased by improving the transport network, especially the railway in countries along the OBOR route. By adopting the Chongqing-Xinjiang-Europe International Railway, the shipment time for goods was reduced compared to maritime transport route. Thus, the OBOR initiative can lower transport costs and improve the world's welfare.

Zhai [30] utilized the computable general equilibrium (CGE) model to investigate the economywide effect of the development of regional infrastructure in Asia. The findings show that infrastructure investment incurs positive externality to the whole economy and leads to a higher social return through lower trading costs. However, Ansar et al. [31] found that infrastructure investments do not typically lead to economic growth, as the typical infrastructure project fails to deliver a positive risk-adjusted return. This is due to the fact that overinvesting in underperforming projects causes a weak financial situation and debt issue. Last but not least, Sun et al. [32] stated that there is no relationship between transportation investment and the national economy due to changes in socio-economic environments. The change of socio-economic is possible that additional transportation investment will become a serious burden to economic growth. As a result, a recession occurred due to high-quality infrastructure.

\subsection{Education}

Fleisher et al. [33] stated that human capital from the aspect of education is significant in explaining the economic growth of China. First, a higher marginal productivity is contributed by the workers 
who possess higher elementary school education. Second, there is a positive and direct effect of human capital on total factor productivity (TFP) growth, which is measured by the proportion of workers with high school educations. Third, an indirect spillover effect of human capital on TFP growth is also proved. This implies that the positive impact of education is more consistent than those found in cross-national studies.

The positive relationship between education and economic growth is supported by Liu and Wang [26] who conducted a study of the New Silk Road and transportation economic zone in China. Two multivariate linear regression equations were formed to estimate a model with and without considering the spatial spillover effect. When the spatial spillover effect was excluded, the result showed that human capital had higher output elasticity. This indicates that human capital and economic growth are significantly and positively correlated in the seven capital cities of China. The result remains constant when the spatial spillover effect on the development of regional economy is included in the model. This is due to the fact that China's higher education developed rapidly after 1999's expansion, when the government put effort into establishing colleges and universities. Yu et al. [34] implied that public education has a persistent positive effect in enhancing economic development in the eastern regions because further maintaining a promising socio-economic environment requires a high-quality education human capital. Additionally, Mihaila [35] asserted that individuals should attain a minimal education level to become intelligent consumers or workers. This can be benefited by the decision making and positive effect of the technological progress of their time. Increasing the human capital can increase the efficiency of production progress time, and in turn expand the profitability and efficiency of a nation's economy.

However, Bils and Klenow [36] performed OLS estimation and found that it is too weak to explain the relationship between education and economic growth, even after taking the effect of schooling on technology into consideration. Moreover, Benhabib and Spiegel [37] also used OLS to estimate the relationship between iterative procedure and discounted investment flows. Their findings indicate that the log difference in human capital is insignificantly correlated to economic growth.

\subsection{Labor Force}

According to Ylander [22], the expansion of infrastructure requires a large number of workers. Therefore, the labor productivity is included to determine the effect of labor force towards gross regional product (GRP) as a proxy for GDP after the implementation of the OBOR initiative in China. The results of OLS analysis show that labor productivity has a positive effect on GRP. For an increase in labor productivity of one yuan, GRP is increased by 2.572 million yuan. This is due to the fact that an upsurge in job opportunities helps to reduce the unemployment rate and raise the GRP of a nation.

Shabani and Safaie [24] analyzed the spatial spillover effect of road and railway infrastructure on economic growth in Iran. The Cobb-Douglas production function was used to examine the relationship between production and input factors in a region. The spatial Durbin model (SDM), spatial autoregressive (SAR), and the Moran's I statistic were also employed in the research. The findings show that there is a positive effect of industrial concentration on economic growth. This is attributed to the availability of abundant labor reserves, which promotes the efficiency of the local labor market by creating a match between employers and employees.

These findings are in line with the study conducted by Juan et al. [38] who used co-integration test to examine the relationship between financial development and economic growth in Western China on the Silk Road Economic Belt. The optimization of the structure of labor force and the improvement of employment quality are believed to promote the economic growth of the nation. On the other hand, Wang et al. [27] employed the spatial error model (SEM) and spatial lag model (SLM) to determine the relationship between labor and economic growth. Their findings show that labor input in non-transport sector makes no significant contribution to economic growth in China. The increase in labor input has a lesser contribution to economic growth due to the high labor supply in China. 
Moreover, Zou et al. [19] compared the effect of labor force and capital investment on economic growth in China using causation test. It was found that the contribution differs significantly in the different regressions. If the Gini coefficient of road is taken into account, the labor growth and capital investment do not help to reduce the regional income inequality. An increase in income inequality leads to a drop in economic growth. Nevertheless, the labor growth and capital investment are augmented when the railway is considered. This reduces income inequality through the spillover effect and trickle-down effect, which in turn encourages the growth of nation's economy.

\subsection{Trade}

Chen and Feng [39] employed OLS to estimate whether international trade affects economic growth in China. The findings indicate that international trade has a positive effect on economic growth. The similar methods used by Cui et al. [40] showed that trade is positively related to the GDP of capital-exporting countries under the OBOR initiative. This implies that the economics in China is highly influenced by the rise of trade dependence in the countries along the Belt and Road.

Furthermore, using three-stage least squares estimation, Mustafa et al. [41] also asserted that trade openness has a positive impact on economic growth. This is due to the fact that trade restructuring in Asian economies has to create new markets with diversified merchandise and better access to products in order to improve consumer welfare. This finding is supported by Zahonogo [42] and Yang and Zhao [43], who stated that the larger the amount of investment in human capital, the greater the impact from trade openness to economic growth. In other words, the improvement of institutional quality leads to trade openness favorable to economic growth.

Juan et al. [38] employed generalized minimum squares (GLS), and identified that foreign trade of western states in the Silk Road economy plays a positive role in stimulating economic growth. This is due to the larger scale of investment in financial development. Additionally, Villafuerte et al. [29] used a GTAP model to assess the impact of OBOR on trade. Their findings indicate that diminishing overall trade costs will improve the trade facilitation in countries along the OBOR route. In turn, this will directly raise the GDP growth in Central, West, and South Asia [44]. Moreover, Zhai [30] used a global CGE model to capture the intensive and extensive margin of trade towards economic growth. The analysis found that the OBOR initiative brings enormous benefits to the world economy in terms of trading and improves the economic welfare of Southeast Asian countries such as Malaysia, Thailand, and Vietnam.

On the other hand, Belloumi [45] performed the Granger causality test on economic growth and trade openness in Tunisia. There was no significant Granger causality from trade to economic growth or from economic growth to trade in the short run. This is because trade openness does not stimulate foreign direct investment (FDI) inflow, which creates new business projects in order to enhance the economic growth of a country.

Meanwhile, some qualitative studies have been performed to investigate the relationship between trade and economic growth. Haggai [46] used a gravity model to analyze the OBOR strategy in China and economic development in the concerning countries. The findings show that the improvement of infrastructure and the promotion of connectivity and foreign relations in the regions are able to reduce trade restrictions. As a result, the trade flow is enriched between China and European countries in order to promote economic development for their citizens. This is in line with the study conducted by Ghanem [47] who analyzed the international trade activities and the level of growth in China.

Additionally, the secondary documentary research technique is applied by Ruankham and Jongsureyapart [48] to explore the development of OBOR in 10 countries. Their findings point out more resources to be shared if more countries engage in trading among the OBOR participant countries. This will shrink the GDP gap between the regions, especially for the underdeveloped countries, through the efficient trading coordination. Last but not least, Qi [49] carried out a descriptive study to demonstrate the importance of bilateral trade framework and how it contributes to international trade and the world economy. With the bilateral trade framework, it provides opportunities for 
sustaining global competitiveness, promoting domestic economic structure, reforming multilateral trade framework, and managing risks.

\subsection{Inflation Rate}

Malik and Chowdhury [50] implemented the Engle-Granger two-step cointegration procedure to examine the connection between inflation and economic growth in four South Asian countries. Their findings reveal that there is a long-term relationship between inflation and economic growth in the four countries. The positive and smaller coefficient designates that inflation is helpful rather than harmful to the growth of the countries. Jarabat [51] also found a positive relationship between inflation and economic growth in Jordan by using a linear regression model.

Chen and Feng [39] studied the variations of economic growth in 29 provinces of China during the period of 1978-1989. The results of OLS analysis show that inflation is negatively related to the growth of the nation's economy. Additionally, Mamo [52] found that inflation has an adverse effect on economic growth. The panel Granger causality test proves that a bidirectional causality existed between inflation and economic growth. Moreover, Gillman et al. [53] support the non-linear negative relationship between inflation and economic growth based on a large panel of OECD and Asia-Pacific Economic Cooperation (APEC) member countries over the years from 1961 to 1997. The increase of inflation was found to cause a more significant reduction of economic growth in the OECD countries compared to the APEC countries.

However, some researchers suggest that there is no significant evidence to prove the relationship between inflation and economic growth. Aria et al. [54] performed generalized method of moments (GMM) to examine the cyclical and casual patterns of inflation and economic growth in 115 countries. When the endogeneity of inflation and dynamics of economic growth were taken into account, it was found that inflation has no effect on economic growth.

Last but not least, Semuel and Nurina [55] used partial least square (PLS) test, and discovered that inflation is not significant for explaining economic growth in Indonesia. This is due to the mild level of inflation in Indonesia, which does not impact the growth of the nation's economy. This is supported by Yii et al. [56] who employed co-integration test and vector error correction model. It was proved that inflation has no significant effect on economic growth in Malaysia. This is because the inflation is controlled by the Malaysian government with efficient economic policies. In conclusion, there is a vast research gap from transportation infrastructure and education regarding the importance of the OBOR initiative in Asian countries.

\section{Methodology}

In this study, panel data analysis is carried out using annual data from the period of 2000-2015, with a total of 176 observations. Eleven selected Asian countries are categorized into three regionsASEAN (Thailand, Indonesia, Vietnam, Malaysia), East Asia (China, Mongolia), and Central Asia (Kazakhstan, Kyrgyz Republic, Tajikistan, Turkmenistan, Uzbekistan). The selected Asian countries are developing countries that are mainly located in the areas surrounding China. The data were collected from the World Development Index (WDI) and the Organisation for Economic Co-operation and Development (OECD). The source of data for each variable is further explained in Table 1. 
Table 1. Description of the variables.

\begin{tabular}{llll}
\hline \multicolumn{1}{c}{ Variables } & \multicolumn{1}{c}{ Proxy } & \multicolumn{1}{c}{ Definition } & \multicolumn{1}{c}{ Sources } \\
\hline GDP & GDP, Annual $\%$ & $\begin{array}{l}\text { Annual percentage growth rate of GDP at } \\
\text { market prices and aggregates are based on } \\
\text { constant local currency and 2010 U.S. dollars. }\end{array}$ & $\begin{array}{l}\text { World } \\
\text { Development } \\
\text { Indicator }\end{array}$ \\
\hline $\begin{array}{l}\text { Transportation } \\
\text { infrastructure }\end{array}$ & $\begin{array}{l}\text { Railways, goods } \\
\text { transported } \\
\text { (million ton-km) }\end{array}$ & $\begin{array}{l}\text { A railway is the system and network of tracks } \\
\text { (rails or railroads) that trains travel on. } \\
\text { Goods transported by railway are the volume } \\
\text { of goods transported by railway. }\end{array}$ & $\begin{array}{l}\text { World } \\
\text { Development } \\
\text { Indicator }\end{array}$ \\
\hline Education & $\begin{array}{l}\text { Human } \\
\text { development index }\end{array}$ & $\begin{array}{l}\text { Human development index (HDI) is a measure } \\
\text { of a country's overall achievement in its social } \\
\text { and economic dimensions. }\end{array}$ & $\begin{array}{l}\text { Organisation for } \\
\text { Economic } \\
\text { Co-operation and } \\
\text { Development }\end{array}$ \\
\hline Trade & Trade (\% of GDP) & $\begin{array}{l}\text { Transaction or process of buying, selling, } \\
\text { or exchanging goods or services, stocks, bonds, } \\
\text { or currency, at either wholesale or retail, within } \\
\text { a country or between the countries. The sum of } \\
\text { exports and imports of goods and services. }\end{array}$ & $\begin{array}{l}\text { World } \\
\text { Development } \\
\text { Indicator }\end{array}$ \\
\hline \multirow{2}{*}{$\begin{array}{l}\text { Labor force } \\
\text { Inflation rate }\end{array}$} & $\begin{array}{l}\text { Labor force, } \\
\text { total labor }\end{array}$ & $\begin{array}{l}\text { All the people who are able to work in a } \\
\text { country or area, or all the people who work for } \\
\text { a particular company. }\end{array}$ & $\begin{array}{l}\text { World } \\
\text { Development } \\
\text { Indicator }\end{array}$ \\
\hline
\end{tabular}

Source: Authors' work. The definitions of variables are derived from WDI and OECD.

\section{Empirical Testing Procedure}

In this study, we use the linear-log regression model to determine the relationship among the variables over the selected countries. The empirical model is expressed as

$$
G D P_{i t}=\beta_{0}+\beta_{1} T D_{1 i t}+\beta_{2} \ln L F_{2 i t}+\beta_{3} E D_{3 i t}+\beta_{4} \ln T I_{4 i t}+\beta_{5} I N F_{5 i t}+\varepsilon_{i t}
$$

where $G D P_{i t}$ denotes GDP growth (annual \%), $T D_{1 i t}$ denotes trade (\% of GDP), $\ln L F_{2 i t}$ denotes logarithm of total labor force, $E D_{3 i t}$ denotes the human development index, $\ln T I_{4 i t}$ denotes logarithm of railways (million ton- $\mathrm{km}$ ), INF $F_{5 i t}$ denotes inflation (annual \%), $\beta_{0}$ is a constant, $\beta_{1}-\beta_{5}$ are the estimated coefficients, $\varepsilon$ is the residual term, $i$ refers to the selected 11 Asian countries, and $t$ is the time span.

The analysis begins with the checking of multicollinearity using the correlation coefficient among the independent variables. Severe multicollinearity is assumed to exist if the absolute value of the correlation coefficient is greater than 0.80 [57]. The variance inflation factor (VIF) is also used to verify the occurrence of multicollinearity. The VIF is the ratio of one and the difference between one and R-squared. The model is classified as a no-correlation problem when the value of VIF is less than or equal to 1 . However, the dependent variable may suffer from a moderate correlated problem if the value is equal to or more than 10 . Multicollinearity problems tend to be less likely to reject the null hypothesis and to have wider confidence intervals [58].

This is followed by applying the unit root test to determine the stationarity of all the time series variables for the panel data [20] In this study, the Fisher-Philips-Perron (PP) test is used to test the existence of the unit root problem. It is believed that the PP test is able to correct for any serial correlation and heteroscedasticity in the error terms [59].

Moreover, the fixed effects model (FEM) is carried out to determine the specific form of the empirical model. According to Williams [58], a fixed effects model is a statistical model in which the explanatory variables consist of non-random quantities. In a fixed effects model, the unobserved 
variables are allowed to have any associations with the observed variables. The impact of specific sample on the outcome is considered as fixed effects. If the model consists of fixed effects, the assumption is usually incorrect.

Random effects model (REM) is known as a hierarchical linear model, mixed model, and multilevel model [60]. A researcher who wishes to verify a possible outcome from a specific factor without concerning fixed values will select a random sample from a larger population. The impact of the random sample on the outcome is considered as a random effect. By including random effects in the model, the violation of error assumption is able to be explained. The restricted maximum likelihood (REML) approach is the mainstream fitting methodology that is used in testing REM [61]. This method does not depend on the fixed-effect estimators, but rather is based on the co-variance matrix estimation for the estimators. Therefore, REML provides more useful estimations, tests, and confidence intervals, even when the data are unbalanced. REM ensures the random effects are normally distributed with zero mean or non-zero variance.

After the testing of FEM and REM, the Hausman test was conducted to determine the misspecification of the econometric model based on the comparison between two different estimators of the model parameters [62]. The estimators must include two properties. First, both estimators must be consistent for the parameters under the null hypothesis of correct model specification. Second, the probability limits on the estimators under the alternative hypothesis of misspecification must be different. The study of White [63] supports that the Hausman test not only applies to linear models and maximum likelihood methods, but that it also extends to quasi-maximum likelihood methods. Furthermore, the Hausman test is also widely used to determine the endogenous regressors in a model to ensure the efficiency of OLS estimator [64]. In panel data analysis, the Hausman test helps in choosing either a fixed effects model or random effects model as preferable for the study. The null hypothesis refering to REM is preferable while the alternative hypothesis is the preference for FEM.

Last but not least, poolability test (POLS) is performed to identify the existence of individual effects and decide whether either the POLS or the FEM is preferable. The pooling of data enables the database to be widened and promotes the reliability of the estimated parameter by studying individual and time effects. The poolability test hypothesizes shows that the POLS method is preferable for null hypothesis while the FEM is preferable as alternative hypothesis [65]. If the test fails to reject the null hypothesis, this shows that all individuals are sufficiently homogeneous and do not need to have specification of the panel model.

\section{Results}

\subsection{Descriptive Statistics}

Table 2 illustrates the descriptive statistics for each variable in the disaggregated and aggregated regions. The mean value of GDP for the three aggregated regions is $6.65 \%$ with a standard deviation of $3.26 \%$. Within the three regions, the highest mean GDP is found for East Asia, with a value of $8.49 \%$ and standard deviation of $3.71 \%$. This proves that East Asia has a fast-growing economy. In East Asia, China has recently become well-known for its resilient growth and has appeared as the second largest economy in the world after the United States. Therefore, it is not surprising that the average GDP of East Asia is higher than that of Central Asia and ASEAN countries. However, the most volatile economic situation is also found in East Asia, as reflected by its having the highest standard deviation. This is due to the fact that East Asia possesses larger financial debt than other countries. In contrast, the lowest value of GDP $(-2.53 \%)$ is found in ASEAN. Following the global financial crisis, ASEAN countries, and especially Malaysia, have been sluggish in their economic recovery.

The statistics show that transportation infrastructure has average value of $210,946.8$ ton-km with a standard deviation of $608,120.20$ ton- $\mathrm{km}$. The maximum value of transportation infrastructure refers to China in East Asia with 2,562,635 ton- $\mathrm{km}$. This is due to China being heavily engaged in the development of infrastructure in line with the OBOR program. In December 2008, the Chinese 
government announced a budget of 4 trillion RMB to enhance the domestic economy [66]. Of these funds, 1.5 trillion RMB is accounted for the development of infrastructure, including railways, roads, irrigation, and airport construction.

The mean education index is 0.67 with a standard deviation of 0.06 . This indicates that education plays an important role in Asian countries where more than $90 \%$ of Asia population can read and write. This is in line with the aspiration to produce more educated and skilled labor for the next generation. ASEAN is the leading region in the education system, which has the mean of 0.68 . The education in the three studied regions has an average performance as there is not much difference between the maximum and minimum value. This indicates that Asian countries are conscious of the importance of education in order to provide a better future for the next generation.

The inflation rate in the Asian countries has a high mean and standard deviation of $10.87 \%$ and $10.16 \%$, respectively. The highest mean inflation is found in Central Asia with a value of $15.55 \%$ and a standard deviation of $11.52 \%$. The rise in the price of food and energy is believed to cause high inflation. The maximum value of inflation rate is found to be $59.74 \%$. This is because the global crisis caused Turkmenistan to suffer from a deficiency in export routes and crucial external debt [67]. Additionally, the prices of necessary food were also accelerated by $30 \%$ in 2008 .

The average performance of trade in the studied countries amounted to $104.57 \%$ with a standard deviation of $42.78 \%$. The highest trade performance was $220.41 \%$ in ASEAN, while the lowest was $39.05 \%$ in East Asia. Bilateral trade between China and ASEAN have been growing over the past 10 years; the exports of ASEAN goods have expanded rapidly against the imports from China [68].

The mean value for the labor force amounted to 91,693,392 people with a standard deviation of 217 million people. Among the three regions, East Asia is claimed to have more job opportunities to drive economic expansion as their countries have the largest mean labor force. According to Statistics Times [69], the population of China is 1.42 billion, the largest population in the world; thus, the participation in the workforce is higher than other countries. This also explains the observation that East Asia has the maximum and minimum size of labor force.

Table 2. Descriptive statistics.

\begin{tabular}{|c|c|c|c|c|c|c|}
\hline Variables & GDP & Education & Inflation Rate & Trade & Transportation Infrastructure & Labor Force \\
\hline \multicolumn{7}{|c|}{ Central Asia } \\
\hline Mean & 7.05 & 0.66 & 15.55 & 96.61 & $43,626.77$ & $5,530,173$ \\
\hline Std. Dev. & 3.38 & 0.06 & 11.52 & 32.02 & $73,758.6$ & $4,116,685$ \\
\hline Maximum & 14.70 & 0.79 & 59.74 & 199.68 & 23,5846 & $14,721,576$ \\
\hline Minimum & -0.47 & 0.54 & -5.15 & 40.87 & 554 & $1,823,595$ \\
\hline \multicolumn{7}{|c|}{ ASEAN } \\
\hline Mean & 5.23 & 0.68 & 6.24 & 125.60 & 3459.52 & $52,585,219$ \\
\hline Std. Dev. & 2.11 & 0.06 & 5.70 & 49.56 & 1582.16 & $37,339,648$ \\
\hline Maximum & 9.43 & 0.79 & 22.67 & 220.41 & 7166 & $123,000,000$ \\
\hline Minimum & -2.53 & 0.58 & -5.02 & 41.87 & 907 & $9,532,646$ \\
\hline \multicolumn{7}{|c|}{ East Asia } \\
\hline Mean & 8.49 & 0.67 & 8.44 & 82.42 & $1,044,222$ & $385,000,000$ \\
\hline Std. Dev. & 3.71 & 0.05 & 8.46 & 33.83 & $1,093,570$ & $391,000,000$ \\
\hline Maximum & 17.29 & 0.74 & 39.18 & 131.33 & $2,562,635$ & $787,000,000$ \\
\hline Minimum & -1.27 & 0.59 & -0.13 & 39.05 & 4293 & 943,715 \\
\hline \multicolumn{7}{|c|}{ Aggregated Regions (Central Asia, ASEAN, East Asia) } \\
\hline Mean & 6.65 & 0.67 & 10.87 & 104.57 & $210,946.80$ & $91,693,392$ \\
\hline Std. Dev. & 3.26 & 0.06 & 10.16 & 42.78 & $608,120.20$ & $217,000,000$ \\
\hline Maximum & 17.29 & 0.79 & 59.74 & 220.41 & $2,562,635$ & $787,000,000$ \\
\hline Minimum & -2.53 & 0.54 & -5.15 & 39.05 & 554 & 943,715 \\
\hline
\end{tabular}

Source: Authors' computations based on descriptive statistics. 


\subsection{Panel Data Regression Model}

Table 3 shows the correlation matrix among the explanatory variables. The correlation coefficients range from 0.0410 to 0.5361 in absolute value. This indicates that there is no multicollinearity problem in the model, as the correlation coefficients are less than 0.80 . To enhance the accuracy of multicollinearity detection, we also calculate the VIF in Table 4. All the VIF values fall between 1.3534 and 2.2635 (i.e., less than 10), indicating that there is no multicollinearity problem in the model.

Table 3. Correlation matrix.

\begin{tabular}{cccccc}
\hline Variables & Education & Inflation Rate & $\ln$ (Labor Force) & $\begin{array}{c}\ln \text { (Transportation } \\
\text { Infrastructure) }\end{array}$ & Trade \\
\hline Education & 1.0000 & & & & \\
Inflation & -0.3230 & 1.0000 & & & \\
$\ln ($ labor force) & 0.0950 & -0.3285 & 1.0000 & 1.0000 & \\
$\ln$ (Transportation infrastructure) & 0.3003 & -0.0410 & 0.5361 & -0.5345 & 1.0000 \\
Trade & 0.1636 & -0.0780 & -0.3672 & & \\
\hline
\end{tabular}

Source: Authors' computations based on correlation analysis.

Table 4. Variance inflation factor (VIF).

\begin{tabular}{ccc}
\hline Independent Variables & $\mathbf{R}^{2}$ & VIF \\
\hline Trade & 0.4062 & 1.6841 \\
$\ln ($ Labor force) & 0.4182 & 1.7188 \\
Education & 0.3309 & 1.4945 \\
$\ln$ (Transportation infrastructure) & 0.5582 & 2.2635 \\
Inflation rate & 0.2611 & 1.3534 \\
\hline
\end{tabular}

Source: Authors' computations based on VIF.

Table 5 shows the results of the panel unit root test using Fisher-PP. When the intercept is included, the variables are found to be stationary at level, except for transportation infrastructure. On the other hand, a panel unit root existed in education, transportation infrastructure, and labor force at level, but turned out to be stationary at first difference. It is concluded that the panel data is stable where the variables have no unit root problem.

Table 5. Panel unit root test.

\begin{tabular}{ccccc}
\hline \multirow{2}{*}{ Variables } & \multicolumn{3}{c}{ Fisher-PP Test } \\
\cline { 2 - 5 } & \multicolumn{2}{c}{ Level } & \multicolumn{2}{c}{ First Difference } \\
\cline { 2 - 5 } & Intercept & Intercept and Trend & Intercept & Intercept and Trend \\
\hline GDP & $76.5385^{* * *}$ & $56.3912^{* * *}$ & $176.272^{* * *}$ & $174.298^{* * *}$ \\
Trade & $49.1484^{* * *}$ & $55.8626^{* * *}$ & $116.344^{* * *}$ & $116.344^{* * *}$ \\
$\ln ($ Labor force) & $101.570^{* * *}$ & 3.0569 & 24.5592 & $51.7609^{* * *}$ \\
Education & $49.3322^{* * *}$ & 9.1603 & $42.2070^{* * *}$ & $61.1958^{* * *}$ \\
$\ln$ (Transportation infrastructure) & $22.2406^{* * *}$ & $15.3043^{* * *}$ & $97.1992^{* * *}$ & $101.224^{* * *}$ \\
Inflation rate & $66.8011^{* * *}$ & $50.6508^{* * *}$ & $202.903^{* * *}$ & $183.516^{* * *}$ \\
\hline
\end{tabular}

Source: Authors' computations based on Fisher-PP analysis. Note: ${ }^{* *}, * *$, and ${ }^{*}$ indicate significance level at 1, 5, and $10 \%$, respectively.

Table 6 shows that the null hypothesis of the Hausman test is rejected, as the random effect ( $p=0.0077)$ is significant at the $1 \%$ level. Therefore, the fixed effects model is the best estimation model to be adopted based on the Hausman test. Using the Poolability F-test helps to increase the accuracy of the result by determining whether either POLS or the FEM is more suitable for a model. The result of the Poolability F-test indicates that the FEM is preferable, as the $p$-value (0.0026) is less than the 
$5 \%$ significance level. In conclusion, the FEM should be employed in this study instead of REM or POLS in order to generate more appropriate outcomes. Besides, the FEM is able to control the stable characteristic of individuals in the model and eliminate the key source of omitted variable bias.

Table 6. Model selection test.

\begin{tabular}{cc}
\hline \multicolumn{2}{c}{ Hausman Test } \\
\hline $\begin{array}{c}\text { Test Summary } \\
\text { Cross-section random }\end{array}$ & $\begin{array}{c}\text { Statistic } \\
\text { Poolability F-Test }\end{array}$ \\
\hline \multicolumn{2}{c}{ Pow* } \\
\hline Cross-section F & $2.8602^{* * *}$ \\
Cross-section Chi-square & $28.9466^{* * *}$ \\
\hline
\end{tabular}

Source: Authors' computations based on Hausman and Poolability F-test analysis. Note: ${ }^{* *}, * *$, and ${ }^{*}$ indicate significance level at 1,5 , and $10 \%$, respectively.

The results of the FEM, shown in Table 7, indicate that the independent variables such as trade, education, transportation infrastructure, and labor force are significant in explaining GDP in the selected Asian countries within the OBOR initiative, however inflation rate is not. The transportation infrastructure is found to have a positive effect on GDP. When there is a $1 \%$ increase in transportation infrastructure, GDP is increased by $0.9131 \%$. The results indicate that further investment in transportation infrastructure, and especially in railways, would increase the nations' GDP. This is in line with the OBOR initiative, where transportation infrastructure is one of the main concentrations. A railway network is planned to be assembled in the Asian countries. Rodrigue and Notteboom [70] stated that the implementation of railway systems facilitates more flexible and high-capacity inland transportation. Substantial economic and social opportunities are provided through the extraction of resources, the settlement of regions, and the growing mobility of freight and passengers. Dowell [71] also claimed that the expansion of transportation infrastructure is able to increase productivity due to the reduction in travel time and enhancement of infrastructure.

Zou et al. [19] and Yang and Ma [20] also found that transportation infrastructure is positively related to GDP. More investment in roads and railways is expected to explore more economy of scale and lead to economic growth in China. Additionally, Demurger [72] found a positive nonlinear and concave relationship between transport infrastructure and GDP, while Villafuerte et al. [29] supported that an improvement in the transportation infrastructure along the OBOR route can raise the GDP growth in Central, West, and South Asia.

The tension between transportation infrastructure and economic growth is in line with Salient Paradox Theory. This tension refers to the mainstream discourse in economics where further investment in transportation infrastructure will increase the efficiency and profitability of the business sector, in turn enhancing the economic growth of the countries [73]. However, Ansar et al. [31] found that the investment in transportation infrastructure does not necessarily lead to economic growth, due to overinvestment in underperforming projects that fails to deliver a positive risk-adjusted return.

The positive coefficient of trade indicates that a $1 \%$ increase in trade raises GDP by $0.0149 \%$. This is because many countries are expected to engage in trade and share the resources through OBOR. With participation in OBOR, the gap between the developed and developing countries is abridged and the nations' economies are improved. This is supported by the studies of Ruankham and Jongsureyapart [48], Cui et al. [40], Haggai [46], and Villafuerte et al. [29] who also found a positive relationship between trade and GDP. Mutual benefit is believed to exist when the countries engage in trading through OBOR.

Surprisingly, education is found to negatively affect GDP; an increase in the human development index leads to a fall in GDP of $14.5001 \%$. This might be due to the inadequacy of the education system in the country. For instance, Central Asia faces several serious challenges in its education systems, such as low school-enrollment (especially by girls), less allocation of education budgets, 
a lack of qualified teachers, and corruption in the system [74]. For example, one Central Asian country, the Kyrgyz Republic, has too many higher education institutions without any effective quality control [75]. Moreover, corruption present in the education system, with "informal payments" securing university admission or excellent examination grades. This is believed to shrink the nation's GDP, as the education system does not contribute in cultivating the potential human capital for economic growth despite the large amount of investment provided by government.

Additionally, the education system in ASEAN countries also appeared to be inadequate. According to UNESCO [76], ASEAN tends to focus on academic performance instead of the relevant curriculum. The relevant curriculum is able to provide students with the skills to be well prepared for the working environment. Otherwise, the graduates are not able to maximize their productivity, which results in a drop in GDP. Moreover, there is also lack of available facilities, teachers, and budget for education in Southeast Asia [77]. The uneven spread of population and the geographical location also impact the development of education systems. For instance, students from remote areas have been found to have difficulty in attending classes due to the insufficiency of transportation systems.

Furthermore, labor force also possesses a negative relationship with GDP in the selected countries. This is due to the fact that the demand for labor force is outstripping its supply, especially in China [78]. The low increase in labor force supply is unable to provide sufficient productivity and increase the nation's GDP. Zou et al. [19] also supported these findings by asserting that the economy of country is exacerbated if the labor growth does not contribute to reducing the income inequality.

The results also indicate that that there is no relationship between inflation rate and GDP. This is supported by Aria et al. [54] who performed a Generalized Method of Moments (GMM) estimator to examine the cyclical and casual patterns of inflation and economic growth in 115 countries. Moreover, Semuel and Nurina [55] also found that inflation is not significantly related to economic growth in Indonesia due to its mild inflation stage. When the inflation rate is anticipated, it does not have a large effect on GDP. This is because consumers are still proactive in their purchasing power [79]. Yii et al. [56] also claimed that inflation has no effect on GDP, due to the implementation of effective economic policies by government in order to control inflation.

Last but not least, the R-squared values indicate that $22.45 \%$ of the variation in GDP can be explained by the variation in trade, education, transportation infrastructure, inflation rate, and labor force. The remaining $77.55 \%$ of the variation in GDP is explained by other factors.

Table 7. Results of the fixed effects model.

\begin{tabular}{ccc}
\hline Independent Variables & Coefficient & $t$-Statistic \\
\hline Trade & $0.0149^{* *}$ & 2.2455 \\
$\ln ($ Labor force) & $-0.3085^{* *}$ & -2.0242 \\
Education & $-14.5001^{* * *}$ & -3.1246 \\
$\ln$ (Transportation infrastructure) & $0.9131^{* * *}$ & 6.2471 \\
Inflation rate & 0.0234 & 0.9300 \\
$\mathrm{C}$ & $11.2365^{* * *}$ & 2.9369 \\
\hline $\mathrm{R}^{2}$ & \multicolumn{2}{c}{0.2245} \\
\hline Adjusted $\mathrm{R}^{2}$ & \multicolumn{2}{c}{0.2017}
\end{tabular}

Source: Authors' computations based on FEM analysis. Note: ${ }^{* * *},{ }^{* *}$, and ${ }^{*}$ indicate significance level at 1,5 , and $10 \%$, respectively.

\section{Conclusions and Policy Implication}

The One Belt One Road (OBOR) initiative is being implemented in order to improve the linkage between China and its neighboring countries in terms of economic ties, connectivity, partnership, and security cooperation. The development of the railway along the Silk Road is taking place in many countries, but different regions have different gauge standards. Therefore, there is a challenge for the proposed railway route in the OBOR initiative to connect the participated countries flawlessly. 
Meanwhile, the problems of education systems—such as budget allocation and lack of skilled educators, especially in ASEAN countries-also cause uncertainty in the OBOR initiative. Therefore, this study aims to examine the importance of determinants such as transportation infrastructure, education, trade, labor force, and inflation rate, on GDP in the selected Asian countries involved in the OBOR initiative. Relevant theoretical models are utilized to support the research framework, such as salient paradox theory, neo-classical theory, and human capital theory. This study additionally employs panel data analysis using annual data from the period of 2000-2015. The fixed effects model (FEM) is chosen based on analysis using the Hausman test and poolability F-test.

The findings reveal that transportation infrastructure has a positive effect on GDP. This implies that the Chinese government and other OBOR-participating countries should further collaborate to expand and upgrade their transportation infrastructure, especially railway systems. For instance, China has allocated a large amount of government spending for transportation projects in collaboration with countries such as Russia, Mongolia, Singapore, Thailand, Indonesia, and Malaysia. This is believed to improve the connectivity between the countries and enhance economic development. Furthermore, the participating countries of the OBOR initiative are also suggested to have rational and effective planning for transportation infrastructure systems in order to lessen the distance between the regions. This helps to create a better opportunity for export activities and to expand the foreign direct investment among the countries.

Education is one of the major concerns in the OBOR initiative. However, the results of this study indicate that education has an inverse relationship with economic growth and affects the efficiency of OBOR. This is due to the fact that most of the participating countries are developing countries with incomplete education systems. To resolve this problem, the participating countries should revise and improve their education policy through effective adaptation, rather than allocating funds to the education sector without proper planning. Furthermore, OBOR participant countries can share their educational resources among each other. For instance, China encourages their universities to set up campus branches in other OBOR countries for the purpose of educational and cultural exchange.

This study is limited by merely including land transportation infrastructure. However, the OBOR initiative is implemented in both land (the Silk Road Economic Belt) and marine (21st Maritime Silk Road) areas. Hence, future researchers are advised to study marine transportation infrastructure. The advanced model is also recommended for future studies to investigate the pre- and post-efficiency of the OBOR initiative.

Author Contributions: Conceptualization, K.-J.Y., K.-Y.B, W.-Y.C., Y.-L.C. and C.-M.L.; Methodology, K.-J.Y., K.-Y.B, W.-Y.C., Y.-L.C. and C.-M.L.; Validation, K.-J.Y., K.-Y.B, W.-Y.C., Y.-L.C. and C.-M.L.; Formal Analysis, K.-Y.B, W.-Y.C., Y.-L.C. and C.-M.L.; Investigation, K.-J.Y., K.-Y.B, W.-Y.C., Y.-L.C. and C.-M.L.; Resources, K.-Y.B, W.-Y.C., Y.-L.C. and C.-M.L.; Data Curation, K.-Y.B, W.-Y.C., Y.-L.C. and C.-M.L.; Writing-Original Draft Preparation, K.-J.Y., K.-Y.B, W.-Y.C., Y.-L.C. and C.-M.L.; Writing-Review \& Editing, K.-J.Y.; Visualization, K.-J.Y., K.-Y.B, W.-Y.C., Y.-L.C. and C.-M.L.; Supervision, K.-J.Y.; Project Administration, K.-J.Y., K.-Y.B, W.-Y.C., Y.-L.C. and C.-M.L.; Funding Acquisition, K.-J.Y.

Funding: Journal paper publication financial support from Universiti Tunku Abdul Rahman, Malaysia.

Conflicts of Interest: The authors declare no conflicts of interest.

\section{References}

1. Chin, H.; He, W. The Belt and Road Initiative: 65 Countries and Beyond. Fung Business Intelligence Center. Available online: https://www.fbicgroup.com/sites/default/files/B\%26R_Initiative_65_Countries_and _Beyond.pdf (accessed on 1 February 2018).

2. Hofman, B. China's One Belt One Road Initiative: What We Know Thus Far. World Bank Blog. Available online: http:/ / blogs.worldbank.org/eastasiapacific/china-one-belt-one-road-initiative-what-w e-know-thus-far (accessed on 1 February 2018).

3. Swaine, M. Chinese Views and Commentary on the 'One Belt, One Road' Initiative. China Leadership Monitor. Available online: https://www.hoover.org/sites/default/files/research/docs/clm47ms.pdf (accessed on 1 February 2018). 
4. Wo-lap, W. Getting Lost in ‘One Belt, One Road. EJ Insight. Available online: http:/ / www.ejinsight.com/20 160412-getting-lost-one-belt-one-road/ (accessed on 1 February 2018).

5. Huang, Z. China's Summit for Its New Silk Road is Missing 44 Heads of State from the 65 Nations Involved. Quartz. Available online: https:/ / qz.com/982202/chinas-summit-for-its-new-silk-road-is-missing-44-he ads-of-state-from-the-65-nations-involved/ (accessed on 1 February 2018).

6. Cheng, M. Belt and Road Initiative: China BRI, One Belt One Road, What Cities and Routes. Available online: https: / / www.cnbc.com/2018/02/15/belt-and-road-initiative-china-bri-one-belt-one-road-what-cities-a nd-routes.html (accessed on 1 February 2018).

7. Yunling, Z. Analysis says One Belt One Road Faces Five Challenges. Available online: https://issuu.com/ davidhallusbct/docs/china_analysis_belt_road/11 (accessed on 1 February 2018).

8. Huawu, H. Key Challenges and Countermeasures with Railway Accessibility along the Silk Road. Engineering 2016, 2, 288-291.

9. Asian Development Bank. Higher Education Across Asia: An Overview of Issues and Strategies. Available online: https:/ / www.adb.org/sites/default/files/publication/29407/higher-education-across -asia.pdf (accessed on 5 February 2018).

10. Ehizuelen, M.M.O. More African Countries on the route: The positive and negative impacts of the Belt and Road Initiative. Transnatl. Corp. Rev. 2017, 9, 341-359. [CrossRef]

11. García, P. Unpublished Interview by Oriol Nierga Llandrich. Tape Recording [In Panish]; Renmin University of China: Beijing, China, 2017.

12. World Bank. China Overview. Available online: http://www.worldbank.org/en/country/china/overview (accessed on 10 February 2018).

13. Smith, W.K.; Lewis, M.W. Toward a theory of paradox: A dynamic equilibrium model of organizing. Acad. Manag. Rev. 2011, 36, 381-403.

14. Margolis, J.; Walsh, J. Misery loves company: Rethinking social initiatives by business. Adm. Sci. Q. 2003, 48, 268-305. [CrossRef]

15. Achour, H.; Belloumi, M. Investigating the causal relationship between transport infrastructure, transport energy consumption and economic growth in Tunisia. Renew. Sustain. Energy Rev. 2016, 56, 988-998. [CrossRef]

16. Aschauer, D.A. Does Public Capital Crowd Out Private Capital? J. Monetary Econ. 1989, 24, 88-171. [CrossRef]

17. Flyvbjery, B.; Sunstein, C.R. The Principle of the Malevolent Hiding Hand or the Planning Fallacy Writ Large. Available online: http:/ / papers.ssrn.com/sol3/Papers.cfm?abstract_id=2654423 (accessed on 18 March 2018).

18. The Economist. America's Transport Infrastructure: Life in the Slow Lane. Available online: https://www. economist.com/united-states/2011/04/28/life-in-the-slow-lane (accessed on 18 March 2018).

19. Zou, W.; Zhang, F.; Zhuang, Z.; Song, H. Transport Infrastructure, Growth, and Poverty Alleviation: Empirical Analysis of China. Ann. Econ. Financ. 2008, 9, 345-371.

20. Yang, C.; Ma, H. The Empirical Research of Transportation Infrastructure Investment and Economic Growth: Based on the Panel Data of "new silk road. ACSR Adv. Comput. 2013, 61, 643-647.

21. Pradhan, R.P.; Samadhan, B.; Pandey, S. Transportation- Communication Infrastructure and Economic Growth: The Panel VAR Application. J. Econ. Soc. Res. 2013, 15, 41-63.

22. Ylander, A. The Impact of 'One Belt, One Road' and its Effects on GDP Growth in China. Dev. Res. Cent. State C. 2017, 87, 291-294.

23. Shi, Y.; Guo, S.; Sun, P. The Role of Infrastructure in China's Regional Economic Growth. J. Asian Econ. 2017, 49, 26-41. [CrossRef]

24. Shabani, Z.D.; Safaie, S. Do transport infrastructure spillovers matter for economic growth? Evidence on road and railway transport infrastructure in Iranian provinces. Rec. Sci. Policy Pract. 2017, 10, 49-63. [CrossRef]

25. Li, J.; Wen, J.; Jiang, B. Spatial Spillover Effects of Transport Infrastructure in Chinese New Silk Road Economic Belt. Int. J. e-Navig. Marit. Econ. 2017, 6, 1-8. [CrossRef]

26. Liu, Y.; Wang, X.A. The Empirical Analysis on the Economy Growth of the New Silk Road Transportation Economic Zone in China-A Panel Data Model on the Basis of Six Factors. In Proceedings of the International Conference on Management and Service Science (MASS), Wuhan, China, 12-14 August 2011. Available online: https://ieeexplore.ieee.org/iel5/5996071/5997898/05999227.pdf (accessed on 20 February 2018). 
27. Wang, X.; Deng, D.; Wu, X. Stimulate economic growth by improving transport infrastructure-a lesson from China. Transp. Prob. 2014, 9, 63-72.

28. Yoshino, N.; Abidhadjaev, U. An impact evaluation of investment in infrastructure: The case of a railway connection in Uzbekistan. J. Asian Econ. 2017, 49, 1-11. [CrossRef]

29. Villafuerte, J.; Chong, E.; Zhuang, J.Z. The One Belt One Road Initiative- Impact on Trade and Growth. Available online: http:/ / china-trade-research.hktdc.com/business-news/article/The-Belt-and-Road-Initi ative/The-One-Belt-One-Road-Initiative-Impact-on-Trade-and-Growth/obor/en/1/1X000000/1X0AA OKG.htm (accessed on 20 February 2018).

30. Zhai, F. China's belt and road initiative: A preliminary quantitative assessment. J. Asian Econ. 2018, 55, 84-92. [CrossRef]

31. Ansar, A.; Flyvbjery, B.; Budzier, A.; Lunn, D. Does infrastructure investment lead to economic growth or economic fragility? Evid. China 2016, 32, 360-390.

32. Sun, J.X.; Li, Z.; Lei, J.; Teng, D.; Li, S. Study on the relationship between Land Transport. Sustainable 2018, 10, 135-151. [CrossRef]

33. Fleisher, B.; Li, H.; Zhao, M.Q. Human Capital, Economic Growth, and Regional Inequality in China. J. Dev. Econ. 2009, 92, 215-331. [CrossRef]

34. Yu, Z.; Zhu, N.; Balezenties, T. Impact of Public Education and Regional Economic Growth in China: A Shadow-Price Perspective. Sustainability 2017, 9, 1333-1342. [CrossRef]

35. Mihaila, R.O.S. Social Investment Economic Growth and Labor Market. Sustainability 2015, 7, $2961-2979$. [CrossRef]

36. Bils, M.; Klenow, P.J. Does Schooling Cause Growth? Am. Econ. Rev. 2000, 90, 1160-1183. [CrossRef]

37. Benhabib, J.; Spiegel, M.M. The Role of Human Capital in Economic Development-Evidence from Aggregate Cross-country Data. J. Monetary Econ. 1994, 34, 143-173. [CrossRef]

38. Juan, S.; Jie, D.; Ping, K. An Analysis of the Relationship between Financial Development and Economic Growth in the Western China on the Silk Road Economic Belt. Int. J. Appl. Econ. Stud. 2016, 4, 2345-5752.

39. Chen, B.; Feng, Y. Determinants of economic growth in China: Private enterprise, education, and openness. China Econ. Rev. 2000, 11, 1-15. [CrossRef]

40. Cui, T.; Liu, J.; Zhang, Z. Research on the growth effect of "the Belt and Road" strategy based on international trade perspective. Adv. Econ. Bus. Manag. Res. 2017, 33, 600-609.

41. Mustafa, G.; Rizov, M.; Kernohan, D. Growth, Human Development, and Trade: The Asian Experience. Econ. Modell. 2017, 61, 93-101. [CrossRef]

42. Zahonogo, P. Trade and Economic Growth in Developing Countries: Evidence from Sub-Saharan Africa. J. Afr. Trade 2016, 3, 41-56. [CrossRef]

43. Yang, H.; Zhao, W. Research on the Influence of Foreign Trade on Upgrading of Industrial Structure in Shaanxi Province- Empirical Analysis Based on New Silk Road Economic Belt. Open J. Bus. Manag. 2016, 4, 528-534. [CrossRef]

44. Zheng, X.; Jia, L. An Empirical Study on the Economic Effect of Financial Cooperation among Countries of the Silk Road Economic Belt. Eng. Econ. 2017, 28, 542-551. [CrossRef]

45. Belloumi, M. The Relationship between Trade, FDI and Economic Growth in Tunisia: An Application of the Autoregressive Distributed Lag Model. Econ. Syst. 2014, 38, 269-287. [CrossRef]

46. Haggai, K. One Belt One Road Strategy in China and Economic Development in the Concerning Countries. World J. Soc. Sci. Hum. 2016, 2, 10-14.

47. Ghanem, O. Applying Gravity Model in International Trade to China's OBOR Policy Initiative. Civ. Environ. Res. 2017, 9, 2224-5790.

48. Ruankham, W.; Jongsureyapart, C. A Rise of China's OBOR to the Regional Economy and Powerm. J. Econ. Manag. Strat. 2017, 4, 1069-1653.

49. Qi, H. The Necessity of Bilateral Trade Framework in Globalization-Case Analysis of Finland under the OBOR. Available online: https:/ / www.theseus.fi/handle/10024/139851 (accessed on 3 March 2018).

50. Malik, G.; Chowdhury, A. Inflation and Economic Growth: Evidence from Four South Asian Countries. Asia-Pac. Dev. J. 2001, 2, 123-135.

51. Jarabat, M.A. Impact of inflation and unemployment on Jordanian GDP. Interdisc. J. Contemp. Bus. 2013, 4, 317-334. 
52. Mamo, F.T. Economic Growth and Inflation (Master's Thesis). Available online: http://sh.diva-portal.org/s mash/record.jsf?pid=diva2\%3A576024\&dswid=-4928 (accessed on 4 March 2018).

53. Gillman, M.; Harris, M.N. Inflation and Growth: Explaining a Negative Effect. Cent. Eur. Univ. 2001, 29, 149-167. [CrossRef]

54. Aria, M.; Kinnwall, M.; Thoursie, P.S. Cyclical and casual patterns of inflation and GDP Growth. Appl. Econ. 2006, 35, 1705-1715.

55. Semuel, Z.D.; Nurina, S. Analysis of the Effect of Inflation, Interest Rates, and Exchange Rates on Gross Domestic Product (GDP) in Indonesia. In Proceedings of the International Conference on Global Business, Economics, Finance and Social Science, Bangkok, Thailand, 20-22 February 2015. Available online: http:/ / repository.petra.ac.id/17008/1/Publikasi1_94033_2021.pdf (accessed on 20 March 2018).

56. Yii, K.J.; Caroline, G.A.; Rosle, A.M. Bank, Stock Market and Environmental Condition towards Economic Growth. An Empirical Evidence in Malaysia from 2000 to 2009. In Proceedings of the Persidangan Kebangsaan Ekonomi Malaysia ke V (PERKEM V), Port Dickson, Malaysia, 15-17 October 2010; pp. 195-209.

57. Gogtay, N.J.; Thatte, U.M. Statistics for Researchers Principles of Correlation Analysis. J. Assoc. Phys. India 2017, 65, 78-81. [PubMed]

58. Williams, R. Multicollinearity. University of Note Dame. Available online: https://www3.nd.edu/ rwillia m/stats2/111.pdf (accessed on 30 March 2018).

59. Phillips, P.C.B.; Perron, P. Testing for Unit Roots in Time Series Regression. Biometrika 1988, 75, 335-346. [CrossRef]

60. Albright, J. Introduction to Random Effects Models, Including HLM. Available online: https://www. methodsconsultants.com/tutorial/introduction-to-random-effects-models-including-hlm/ (accessed on 2 April 2018).

61. Patterson, H.D.; Thompson, R. Maximum Likelihood Estimation of Components of Variance. In Proceedings of the Eighth International Biometric Conference, Constanța, Romania, 25-30 August 1974; pp. 197-207.

62. Hausman, J.A. Specification Tests in Econometrics. J. Econom. Soc. 1978, 46, 1251-1271. [CrossRef]

63. White, H. Estimation, Inference and Specification Analysis; Cambridge University Press: Cambridge, UK, 1994.

64. Stephanie. Hausman Test for Endogeneity (Hausman Specification Test). Available online: http:/ / www.stat isticshowto.com/hausman-test/ (accessed on 10 April 2018).

65. Kunst, R.M. Econometric Methods for Panel Data-Part II. University of Vienna. Available online: https: / / homepage.univie.ac.at/robert.kunst/panels2e.pdf (accessed on 11 April 2018).

66. KPMG. Infrastructure in China: Foundation for Growth. Available online: https://www.kpmg.de/docs/Inf rastructure_in_China.pdf (accessed on 11 April 2018).

67. Gencer, E.A.H.; Gernc, C. Central Asian Economies in Transition; Cambridge Scholar: Newcastle, UK, 2012.

68. Yin, X.M. China's Intermediate Goods Trade with ASEAN: A Profile of Four Countries. Available online: http:/ / www.ide.go.jp/library/English/Publish/Download/Brc/pdf/05_chapter3.pdf (accessed on 28 May 2018).

69. Times Statistics. China vs India by Population. Available online: http://statisticstimes.com/population/chi na-vs-india-population.php (accessed on 28 May 2018).

70. Rodrigue, J.P.; Notteboom, T. The Geography of Transport Systems. Available online: https://transportgeo graphy.org/?page_id=5260 (accessed on 30 May 2018).

71. Dowell, P. The Top Five Ways Transportation Impacts Economic Development. Available online: https: / / csengineermag.com/article/top-five-ways-transportation-impacts-economic-development/ (accessed on 30 May 2018).

72. Demurger, S. Infrastructure development and economic growth: An explanation for regional disparities in China? J. Comp. Econ. 2001, 29, 95-117. [CrossRef]

73. Ansar, A. Location Decisions of Large Firms: Analyzing the Procurement of Infastructure Services. J. Econ. Geogr. 2012, 13, 823-844. [CrossRef]

74. Organization for Security and Co-Operation. Current Education Issues in Central Asia. Background Paper of Conflict Prevention Centre. Available online: https://www.osce.org/cpc/39626?download=true (accessed on 1 June 2018).

75. Heyneman, S.P.; Young, A.J.D. The Challenges of Education in Central Asia. Arizona State University. Available online: http:/ / www.infoagepub.com/products/The-Challenges-of-Education-in-Central-Asia (accessed on 1 June 2018). 
76. UNESCO. Education Systems in ASEAN+6 Countries: A Comparative Analysis of Selected Educational Issues. Available online: http:/ / unesdoc.unesco.org/image/0022/002267/22675E.pdf (accessed on 1 June 2018).

77. Sadiman, A.S. Challenge in Education in ASEAN. SEAMEO Library. Available online: http://www.seameo .org/vl/library/dlwelcome/publications/paper/india04.htm (accessed on 1 June 2018).

78. Chandrasekhar, C.P.; Ghosh, J. China's Labour Market Conundrum. Available online: https://www.thehindubu sinessline.com/opinion/columns/c-p-chandrasekhar/chinaslabour-market-conundrum/article9747186.ece (accessed on 1 June 2018).

79. Cozad, M. Anticipated Inflation: Definition \& Overview. Available online: https://study.com/academy/le sson/anticipated-inflation-definition-lesson-quiz.html (accessed on 2 June 2018).

C 2018 by the authors. Licensee MDPI, Basel, Switzerland. This article is an open access article distributed under the terms and conditions of the Creative Commons Attribution (CC BY) license (http://creativecommons.org/licenses/by/4.0/). 